\title{
PENDIDIKAN ISLAM DI SURIAH DAN RELEVANSINYA DENGAN PENDIDIKAN ISLAM DI INDONESIA
}

\author{
Mardhiya Agustina \\ Dosen, STAI Rasyidiyah Khalidiyah Amuntai, Kalimantan Selatan, \\ Indonesia \\ mardhiya@yahoo.co.id
}

\begin{abstract}
Abstrak
Suriah merupakan negara yang berada di Jazirah Arab dan merupakan salah satu negara yang menjadi saksi sejarah perkembangan Islam dan pendidikannya. Suriah yang juga dikenal sebagai Bilad al-Syam disinyalir sebagai pusat peradaban pertama dan tertua di dunia dimana Sham putera Nabi Nuh as memilih untuk tinggal di sana setelah bahtera Nuh merapat, dan merupakan tempat yang dituju Rasulullah saw untuk perjalanan bisnisnya. Sekarang Suriah berada pada kondisi perang saudara yang juga memberikan dampak negatif terhadap pendidikan di sana. Sebelum perang berkecamuk, Suriah merupakan salah satu negara yang sering dituju oleh para mahasiswa muslim dari berbagai negara sebagaimana Mesir, Arab Saudi, Libya, Maroko, dan Tunisia. Oleh karena itu menarik untuk diteliti bagaimana pendidikan Islam disana dilihat dari sistem dan kelembagaannya. Sehingga kemudian dapat diketahui bagaimana relevansinya dengan pendidikan agama Islam di Indonesia. Penelitian ini merupakan penelitian kepustakaan yang datanya diperoleh melalui berbagai literatur baik berupa buku, jurnal, dan semacamnya yang berhubungan dengan pembahasan. Peneliti kemudian menguraikan hasil temuan dan melakukan analisis isi kemudian mengambil kesimpulan. Hasil penelitian menunjukkan bahwa relevansi pendidikan Islam di Suriah dengan pendidikan Islam di Indonesia dapat dilihat dari beberapa sudut, yaitu: (1) Lembaga pendidikan, memiliki lembaga pendidikan formal seperti madrasah, perguruan tinggi dan ma'had 'aliy, dan non formal seperti masjid, halaqah ta'lim, halaqah tahfizh al-Qur'an; (2) Jenjang pendidikan, dimulai dari tingkat dasar, persiapan, menengah dan perguruan tinggi; (3) Wajib belajar, lamanya 9 tahun (4) Biaya pendidikan gratis, untuk seluruh jenjang pendidikan pada lembaga pendidikan milik pemerintah.
\end{abstract}

Keywords: Pendidikan Islam, Pendidikan Islam di Suriah, Pendidikan Islam di Indonesia

\section{A. Pendahuluan}

Pendidikan dalam Islam berkembang seiring dengan perkembangan Islam itu sendiri. Sehingga pendidikan Islam memiliki sejarah yang sangat

Jurnal Ilmiah Al QALAM, Vol. 12, No. 1, Januari-Juni 2018 
Mardhiya Agustina: Pendidikan Islam di Suriah dan Relevansinya dengan Pendidikan Islam di Indonesia

panjang dari awal munculnya Islam hingga sekarang. Jika dilihat dari tempat awal Islam muncul dan berkembang yaitu di jazirah Arab, kedatangan Islam membawa perubahan besar bagi masyarakat Arab dalam konteks pendidikan Islam. Dimana lembaga pendidikan formal belum yang tersistem dengan sedemikian rupa belum ditemukan pada masyarakat Arab. Pendidikan Islam terjadi sejak nabi Muhammad saw diangkat menjadi Rasul dan beliau sendiri yang menjadi guru pertamanya. ${ }^{95}$

Sejarah Islam mencatat bahwa studi Islam telah berkembang sejak masa awal dunia Islam. Tumbuhnya lembaga pendidikan diilhami oleh ajaran Islam itu sendiri, yang menyatakan bahwa pendidikan merupakan kewajiban bagi setiap muslim. ${ }^{96}$ Pada awal perkembangan Islam tentunya belum ada kegiatan pendidikan yang diselenggarakan secara sistematis dan berbentuk formal, diketahui secara luas bahwa lembaga pendidikan pertama non formal pada masa Rasulullah adalah di rumah Al-Arqam, kemudian kuttab, masjid, dan suffah. Kemudian seiring dengan berkembangnya Islam di berbagai Negara Arab, tumbuh berkembang pula lembaga pendidikan Islam yang bersifat formal dengan lahirnya madrasah pertama dalam sejarah pendidikan Islam yaitu Madrasah Nizhamiyah di Baghdad.

Salah satu Negara Arab yang menjadi saksi sejarah perkembangan Islam dan pendidikannya adalah Suriah. Negara Suriah atau yang juga dikenal dengan Syria adalah Negara yang dituju oleh Rasulullah saw ketika beliau melakukan perjalanan bisnisnya. Suriah ber-ibukota Damaskus (dalam Bahasa Arab Dimasyqa) yang terkenal sebagai kota tempat berkembangnya ilmu pengetahuan Islam. Namun sekarang Suriah sedang berada dalam kondisi perang yang mengakibatkan lumpuhnya stabilitas Negara dan juga lumpuhnya sistem pendidikan. Artikel ini bertujuan untuk meneliti dan kemudian

95 Abudin Nata, Sejarah Pendidikan Islam: Pada Periode Klasik dan Pertengahan, (Jakarta: Raja Grafindo Persada, 2004), cet.1, h.10.

${ }^{96}$ Azyumardi Azra, Pendidikan Islam: Tradisi dan Modernisasi Menuju Milenium Baru, (Ciputat: Logos Wacana Ilmu, 1999), cet.1. h.22.

Jurnal Ilmiah Al QALAM, Vol. 12, No. 1, Januari-Juni 2018 
Mardhiya Agustina: Pendidikan Islam di Suriah dan Relevansinya dengan Pendidikan Islam di Indonesia

mendeskrepsikan bagaimana pendidikan Islam di Suriah dan bagaimana relevansinya dengan pendidikan Islam di Indonesia.

\section{B. Tinjauan Geografis dan Tinjauan Historis Negara Suriah}

Suriah pada awalnya merupakan bagian dari Negara Republik Arab. Republik Arab Suriah dalam bahasa Arabnya al-jumhuriyyah al-arabiyyah alsuriyah dan dalam bahasa Inggris Syria, adalah Negara yang terletak di Timur Tengah, dengan Negara Turki di sebelah utara, Irak di Timur, Laut Tengah di Barat dan Yordania di Selatan. Berdasarkan data yang diperoleh dari CIA World Factbook 2004 jumlah penduduk Suriah berjumlah 18.016.874.suriah terdiri dari pegunungan di sebelah Barat dan gurun di sebelah Timur dan Selatan. Ibukota Suriah bernama Damaskus. Dulu kota Damaskus bernama Bilad al-Sham atau tanah Sham. Nama Sham atau Sam diambil dari kata Shem, putra tertua Nabi Nuh as yang memilih tinggal di wilayah itu setelah banjir bandang. ${ }^{97}$

Kota Damaskus diperkirakan merupakan kota tertua di dunia yang sudah ada sejak 6000 tahun SM, bahkan ada yang berpendapat sudah ada sejak 8000 tahun SM. Suriah mempunyai sejarah panjang. Negeri ini pernah menjadi wilayah jajahan kerajaan Assiria.Saat itu tahun 732 SM, penguasa Assiria adalah raja Tiglath Pilesser III. Kemudian Damaskus jatuh ke tangan Nebukadnesar dari Neo-Babilonia, sekitar tahun 572 SM. Pada tahun 538 SM, Damaskus sudah jatuh ke tangan raja Cyrus dari Persia dan mulai saat itu Damaskus dijadikan pusat pemerintahan dan militer Provinsi Suriah. Pada tanggal 23 Februari 635M masa kekhalifahan Umar bin Khattab Islam berhasil masuk ke Suriah yaitu di bawah komando Khalid bin Al-Walid yang berhasil

${ }^{97}$ Mahadhir Muhammad, Kebijakan Politik Pemerintahan Bashar Al-Assad di Suriah, In Right Jurnal Agama dan Hak Azazi Manusia Vol.6 No.1 November 2016, h.101-102.

Jurnal Ilmiah Al QALAM, Vol. 12, No. 1, Januari-Juni 2018 
Mardhiya Agustina: Pendidikan Islam di Suriah dan Relevansinya dengan Pendidikan Islam di Indonesia

mengalahkan musuh di Marja Shufar. Dua minggu kemudian, Khalid berdiri di gerbang kota Damaskus. ${ }^{98}$

Pada tahun 664, Damaskus dijadikan sebagai ibukota pemerintahan oleh Muawiyah.Meskipun dinasti ini memrintah Damaskus kurang dari 100 tahun, tetapi sumbangan yang diberikan sangat besar dan berarti, terutama di bidang kebudayaan dan seni.Peninggalan diinasti Umayyah yang kini masih berdiri megah adalah Masjid Umayyah atau sering disebut Masjid Umawwi atau Masjid Agung. Masjid ini terletak di kawasan kota lama Damaskus. Pemrakarsa pembangunan masjid ini adalah Walid bin Abdul Malik. Tempat di mana sekarang Masjid Umayyah berdiri, sejak dulu merupakan pusat peribadatan penguasa Damaskus. ${ }^{99}$

Suriah memiliki bahasa resmi bahasa Arab dengan mata uang Pound Syria. Sebagai sebuah Negara dengan berbagai entitas di dalamnya, Suriah terdiri atas mayoritas komunitas muslim Sunni 75\%, yang secara historis tetap dominan, dan beberapa komunitas minoritas lainnya: Kristen 19\% dan beberapa sekte Islam heterodoks, Alawiy 11,5\%, Druze 3\%, dan Ismaily 1,5\% yang sebagian besar di pedesaan, khususnya kaum Alawiy. Suriah merupakan negeri yang sudah dihuni manusia sejak zaman batu.Bukti arkeologi menunjukkan bahwa Suriah pernah menjadi salah satu pusat peradaban tertua di dunia.Karena terletak di persilangan jalur perdagangan dan militer antara Laut Tengah, Mesopotamia, dan Mesir, maka Suriah menjadi sasaran penyerbuan dari negaranegara tetangganya. ${ }^{100}$

Sejak tahun 2000, Suriah dipimpin oleh rezim Assad.Setelah meninggalnya Hafiz Al-Assad, pemerintahan dilanjutkan oleh puteranya Bashar

${ }^{98}$ Mahadhir Muhammad, Kebijakan Politik Pemerintahan Bashar Al-Assad di Suriah, In Right Jurnal Agama dan Hak Azazi Manusia Vol.6 No.1 November 2016, h. 102

${ }^{99}$ Mahadhir Muhammad, Kebijakan Politik Pemerintahan Bashar Al-Assad di Suriah, In Right Jurnal Agama dan Hak Azazi Manusia Vol.6 No.1 November 2016, h. 103

${ }^{100}$ Mahadhir Muhammad, Kebijakan Politik Pemerintahan Bashar Al-Assad di Suriah, In Right Jurnal Agama dan Hak Azazi Manusia Vol.6 No.1 November 2016, h.103-104

Jurnal Ilmiah Al QALAM, Vol. 12, No. 1, Januari-Juni 2018 
Mardhiya Agustina: Pendidikan Islam di Suriah dan Relevansinya dengan Pendidikan Islam di Indonesia

Al-Assad. Rezim Assad mengintegrasikan militer ke dalam rezim, juga memperkuat kekuasaannya dengan membangun jaringan yyang loyal dan menempatkannya pada posisi-posisi penting. Pada akhirnya, militer, aparat, dan para kaum eliit begitu menyatu dan sangat sulit dipisahkan dari rezim Assad. ${ }^{101}$

\section{Sistem Pendidikan Agama Islam di Suriah}

\section{Jenjang Pendidikan Islam di Suriah}

Jenjang pendidikan di Suriah baik pada lembaga pendidikan Islam maupun lembaga pendidikan umum terdiri dari 4 jenjang pendidikan:

a. Al-Marhalah al-Ibtidaiyyah; yang terdiri dari 6 jenjang kelas ditempuh dalam waktu 6 tahun.

b. Al-marhalah al-I'dadiyyah; yang terdiri dari 3 jenjang kelas ditempuh dalam waktu 3 tahun.

c. Al-marhalah al-Tsanawiyyah; yang terdiri dari 3 jenjang kelas ditempuh dalam waktu 3 tahun.

d. Al-marhalah al-Jami'iyyah; yang ditempuh dalam kurun waktu ${ }^{102}$

\section{Lembaga Pendidikan Islam di Suriah}

Pendidikan di Suriah pada lembaga pendidikan formal milik pemerintah seluruhnya gratis. Dan pendidikan pada jenjang Al-Marhalah al-Ibtidaiyyah dan Al-marhalah al-I'dadiyyah adalah wajib bagi setiap Warga Negara Suriah. Selain lemabaga pendidikan milik pemerintah juga terdapat lembaga pendidikan milik swasta yang berbayar.

Dalam sistem pendidikan di Suriah terdapat beberapa jenis lembaga Pendidikan Islam formal yaitu Madrasah, Perguruan Tinggi dan Ma'had 'Aliy yang juga setara dengan perguruan tinggi. Untuk madrasah tingkat al-tsanawiyyah memiliki beberapa jenis:

${ }^{101}$ Mahadhir Muhammad, Kebijakan Politik Pemerintahan Bashar Al-Assad di Suriah, In Right Jurnal Agama dan Hak Azazi Manusia Vol.6 No.1 November 2016, h. 104

${ }^{102}$ Google Play Store,Al-Maktabah Al-Madrasiyyah Al-Suriyyah

Jurnal Ilmiah Al QALAM, Vol. 12, No. 1, Januari-Juni 2018 
Mardhiya Agustina: Pendidikan Islam di Suriah dan Relevansinya dengan Pendidikan Islam di Indonesia

a. Madrasah syar'iyyah ammah yang mengajarkan ilmu keagamaan dan juga sains dibiayai dari dana zakat dari badan zakat pemerintah dan donasi dari para donatur

b. Madrasah syar'iyyah khashah mengajarkan mata pelajaran sebagaimana madrasah syar'iyyah ammah hanya saja pembiayaannya dilakukan oleh pihak swasta. ${ }^{103}$

c. Madrasah tsanawiyyah ammah yang mempelajari keilmuan dan kesusasteraan dibiayai oleh pemerintah.

d. Madrasah tsanawiyyah mihaniyyah yang mempelajari ilmu-ilmu kejuruan seperti: bisnis, perindustrian, kewanitaan, pertanian, perhotelan yang dimiliki pemerintah dibiayai oleh pemerintah dan milik swasta dibiayai oleh swasta.

Adapun perguruan tinggi juga terdiri dari perguruan tinggi milik pemerintah yang gratis seperti Universitas Damaskus, Universitas Aleppo dll, dan perguruan tinggi milik swasta yang berbayar seperti Universitas Andalusia, Universitas Yarmuk dll. ${ }^{104}$

Sedangkan lembaga pendidikan Islam non formal yang terdapat di Suriah seperti masjid, halaqah ta'lim, halaqah tahfizh al-Qur'an.

a. Masjid; salah satu masjid terbesar di Suriah yang menjadi pusat pengajaran Islam adalah Masjid Umawwiy, di mana dilakukan berbagai kegiatan keagamaan dan pendidikan keagamaan.

b. Halaqoh ta'lim; pada prakteknya halaqah ta'lim ini diselenggarakan di berbagai tempat, seperti rumah masyarakat, gedung pertemuan dll. Pada halaqah ta'lim ini diajarkan pendidikan keagamaan dan juga pengajaran membaca Al-Quran untuk berbagai jenjang usia.

103 Al-Islam Fi Suriya, https://ar.m.wikipedia.org/wiki/الإسلام في سوريا2, diakses pada 16 April 2018

${ }^{104}$ Al-Ta'lim Fi Suriya, https://ar.m.wikipedia.org/wiki/التعليم في_سوريا/2 diakses pada 16 April 2018

Jurnal Ilmiah Al QALAM, Vol. 12, No. 1, Januari-Juni 2018 
Mardhiya Agustina: Pendidikan Islam di Suriah dan Relevansinya dengan Pendidikan Islam di Indonesia

c. Halaqoh tahfizh al-Qur'an; sebagaimana halaqah ta'lim dilaksanakan di berbagai tempat untuk pendidikan menghafal AlQur'an dimulai dari jenjang usia dini.

\section{Kurikulum Pendidikan Islam di Suriah}

Untuk mengetahui bagaimana kurikulum pendidikan Agama Islam di Suriah, penulis paparkan terlebih dahulu secara keseluruhan kurikulum pada masing-masing jenjang pendidikan di atas, yaitu sebagai berikut:

a. Al-Marhalah al-Ibtidaiyyah;

1) Pada kelas 1 diajarkan mata pelajaran Bahasa Arab, Matematika, Sains, Bahasa Inggris, Pendidikan Seni

2) Pada kelas 2 diajarkan mata pelajaran Bahasa Arab, Matematika, Sains, Bahasa Inggris, Pendidikan Seni

3) Pada kelas 3 diajarkan mata pelajaran Bahasa Arab, Matematika, Sains, Bahasa Inggris, Pendidikan Sosial, Pendidikan Agama Islam/ Kristen, Pendidikan Seni

4) Pada kelas 4 diajarkan mata pelajaran Bahasa Arab, Matematika, Sains, Bahasa Inggris, Pendidikan Sosial, Pendidikan Agama Islam/ Kristen, Pendidikan Seni

5) Pada kelas 5 diajarkan mata pelajaran Bahasa Arab, Matematika, Sains, Bahasa Inggris, Pendidikan Sosial, Pendidikan Agama Islam/ Kristen, Pendidikan Seni

6) Pada kelas 6 diajarkan mata pelajaran Bahasa Arab, Matematika, Sains, Bahasa Inggris, Pendidikan Sosial, Pendidikan Agama Islam/ Kristen, Pendidikan Seni

b. Al-marhalah al-I'dadiyyah; yang terdiri dari 3 jenjang kelas ditempuh dalam waktu 3 tahun.

Jurnal Ilmiah Al QALAM, Vol. 12, No. 1, Januari-Juni 2018 
Mardhiya Agustina: Pendidikan Islam di Suriah dan Relevansinya dengan Pendidikan Islam di Indonesia

1) Pada kelas 7 diajarkan mata pelajaranBahasa Arab, Bahasa Inggris, Bahasa Rusia, Bahasa Perancis, Ilmu Biologi Dan Bumi, Kimia, Fisika, Teknologi Informatika, Wawasan Keilmuan, Pendidikan Agama Islam/ Kristen, Matematika, Pendidikan Kewarganegaraan, Geografi, Sejarah, Pendidikan Seni

2) Pada kelas 8 diajarkan mata pelajaran Bahasa Arab, Bahasa Inggris,Bahasa Rusia, Bahasa Perancis, Ilmu Biologi Dan Bumi, Kimia, Fisika, Teknologi Informatika, Wawasan Keilmuan, Pendidikan Agama Islam/ Kristen, Matematika, Pendidikan Kewarganegaraan, Geografi, Sejarah, Pendidikan Seni,Tehnik, Aljabar.

3) Pada kelas 9 diajarkan mata pelajaran Bahasa Arab, Bahasa Inggris, Matematika Aljabar, Matematika Tehnik, Ilmu BiologiDan Bumi, Fisika, Kimia, Geografi, Sejarah, Pendidikan Kewarganegaraan, Pendidikan Agama Islam/ Kristen, Pendidikan Musik, Pendidikan Seni.

c. Al-marhalah al-Tsanawiyyah; yang terdiri dari 3 jenjang kelas ditempuh dalam waktu 3 tahun.

1) Pada kelas 1 diajarkan mata pelajaran:

(a) Kelas Umum: Bahasa Arab dan Sastra, Bahasa Inggris, Matematika Aljabar, Matematika Tehnik, Ilmu Biologi dan Lingkungan, Fisika, Kimia, Pengantar Filsafat, Pengantar Ilmu Sosial, Pengantar Ilmu Psikologi, Geografi, Sejarah Kebudayaan, Pendidikan Kewarganegaraan, Pendidikan Agama Islam/ Kristen, Pendidikan Seni

(b) Kelas Bisnis: Dasar-Dasar Akuntansi, Statistik, Matematika Keuangan, Dasar-Dasar Manajemen dan Kesekretariatan, Prinsip Perundangan Profesi dan Perdagangan, Aplikasi Komputer Akuntansi dalam Ilmu Perdagangan.

Jurnal Ilmiah Al QALAM, Vol. 12, No. 1, Januari-Juni 2018 
Mardhiya Agustina: Pendidikan Islam di Suriah dan Relevansinya dengan Pendidikan Islam di Indonesia

2) Pada kelas 2 diajarkan mata pelajaran:

(a) Kelas Sains: Bahasa Arab dan Sastra, Bahasa Inggris,Fisika, Kimia,Ilmu Biologi dan Bumi, Matematika, Matematika Aljabar, Ilmu Filsafat dan Sosial dan Psikologi, Pendidikan Kewarganegaraan, Sejarah Perkembangan Tehnik di Dunia, Pendidikan Agama Islam/ Kristen, Pendidikan Seni.

(b) Kelas Sastra: Bahasa Arab dan Sastra,Bahasa Inggris,Ilmu Filsafat dan Sosial dan Psikologi, Geografi, Sejarah Dunia Modern, Pendidikan Kewarganegaraan,Pendidikan Agama Islam/ Kristen, Pendidikan Seni, Matematika, Wawasan Keilmuan

(c) Kelas Bisnis: Dasar-Dasar Akuntansi, Statistik, Matematika Keuangan, Prinsip Ekonomi, Akuntansi Perpajakan, Manajemen Pengadaan Barang dan Pergudangan, Aplikasi Komputer dalam Ilmu Bisnis

3) Pada kelas 2 diajarkan mata pelajaran:

(a) Kelas Sains: Bahasa Arab dan Sastra, Bahasa Inggris, Matematika Al-Jabar, Matematika Tehnik Analitik, Matematika Analisis Matematis, Fisika, Kimia, Ilmu Biologi, Pendidikan Kewarganegaraan, Pendidikan Agama Islam/ Kristen.

(b) Kelas Sastra: Bahasa Arab dan Sastra, Bahasa Inggris,Ilmu Filsafat dan Sosial dan Psikologi, Geografi, Sejarah Negara Arab Modern Masa Kini, Pendidikan Kewarganegaraan, Pendidikan Agama Islam/ Kristen.

(c) Kelas Bisnis: Akuntansi Pribaadi, Akuntansi Lembaga Keuangan, Akuntansi Pembiayaan, Matematika dan 
Mardhiya Agustina: Pendidikan Islam di Suriah dan Relevansinya dengan Pendidikan Islam di Indonesia

Statistik, Matematika Keuangan, Aplikasi Komputer dalam Ilmu Bisnis, Prinsip Pemasaran. ${ }^{105}$

d. Al-marhalah al-Jami'iyyah; pada jenjang ini dipelari keilmuan sesuai dengan masing-masing jurusan dengan tetap memasukkan pendidikan keagamaan.

Berdasarkan uraian kurikulum diatas dapat disimpulkan bahwa pendidikan agama Islam di Suriah mulai diajarkan pada lembaga pendidikan formal pada kelas 3 jenjang Al-Marhalah al-Ibtidaiyyah hingga jenjang perguruan tinggi.

\section{Analisis relevansi Pendidikan Islam di Suriah dengan Pendidikan Islam di Indonesia}

Berdasarkan pemaparan di atas, bila ditinjau dari jenis lembaga pendidikan di Suriah, memiliki kesamaan dengan jenis lembaga pendidikan di Indonesia, yaitu berupa madrasah, universitas, majelis ilmu dan halaqah. Sistem pendidikan di Suriah gratis untuk seluruh rakyat Suriah. Begitu juga lembaga pendidikan yang resmi dikelola oleh pemerintah Indonesia juga gratis dari sekolah dasar sampai sekolah menengah atas, adapun perguruan tinggi tidak ditanggung oleh pemerintah kecuali beasiswa.

Madrasah di Suriah memegang peranan penting dalam perkembangan pendidikan Islam. Sebagaimana di Indonesia juga, madrasah merupakan aset negara sebagai lembaga pendidikan Islam yang menjadi wadah membentuk karakter Islami generasi bangsa. Jika di Suriah terdapat madrasah yang berbentuk sekolah formal dan adapula semacam majlis, sedang di Indonesia madrasah saat ini adalah berbentuk formal, baik yang terinterasi dengan pesantren, ataupun milik negara maupun swasta. Meskipun madrasah pada kedua negara pada zaman sekarang bersaing ketat dengan lembaga pendidikan lain berbentuk sekolah, namun madrasah tetap mendapatkan tempat di hati

${ }^{105}$ Google Play Store, Al-Maktabah Al-Madrasiyyah Al-Suriyyah

Jurnal Ilmiah Al QALAM, Vol. 12, No. 1, Januari-Juni 2018 
Mardhiya Agustina: Pendidikan Islam di Suriah dan Relevansinya dengan Pendidikan Islam di Indonesia

masyarakat muslim, dimana ia tumbuh dan berkembang sejalan dengan kultur masyarakat setempat. Dan dari tinjauan sisi sosial budaya, masyarakat muslim menganggapnya sebagai warisan budaya pendidikan Islam dan wadah untuk mereka mempelajari ilmu keIslaman. ${ }^{106}$

Lembaga pendidikan di negara Suriah sangat dimonitoring oleh kementerian pendidikan agar kegiatan belajar mengajar tidak lepas dari visi misi negara. Berbeda dengan lembaga pendidikan di Indonesia terjadi dualisme, kementerian agama mengelola lembaga pendidikan Islam dan kementerian riset dan teknologi mengelola lembaga pendidikan umum. Dualisme ini berakibat berpengaruhnya kepada kebijakan publik, keuangan dan sebagainya. Pada masa sebelum kemerdekaan, di Indonesia terjadi dikotomi pendidikan antara pendidikan agama dan sains, namun setelah kemerdekaan pendidikan agama terintegrasi ke dalam sistem pendidikan nasional, sejarah ini juga yang diantaranya melatar belakangi terjadinya dualisme pengelolaan lembaga pendidikan di Indonesia. ${ }^{107}$

Bila ditinjau dari lama jenjang pendidikan pra universitas juga memiliki kesamaan dengan lama jenjang pendidikan di Indonesia yaitu 12 tahun dari jenjang pendidikan dasar hingga menengah. Hanya saja di Suriah diterapkan wajib belajar 9 tahun dari jenjang ibtidaiyyah hingga i'dadiyyah, sedangkan di Indonesia wajib belajar 12 tahun dari jenjang pendidikan dasar hingga menengah atas.

Materi Pendidikan Agama Islam dalam pendidikan di Suriah diajarkan pada lembaga formal mulai kelas 3 Al-Marhalah al-Ibtidaiyyah sedangkan di Indonesia mulai diajarkan sejak kelas 1 Sekolah Dasar atau Madrasah Ibtidaiyyah. Sedangkan kesamaan kedua negara dalam pendidikan Islam pada lembaga non formal adalah sama-sama memiliki tradisi pembelajaran di majlismajlis ilmu pada berbagai jenjang usia.

${ }^{106}$ Lihat Suwito, Fauzan, Sejarah Sosial Pendidikan Islam, (Jakarta: Prenada Media, 2005), cet.1, h.209-210.

${ }^{107}$ Lihat Haidar Putra Daulay, Dinamika Pendidikan Islam di Asia Tenggara, (Jakarta: Rineka Cipta, 2009), cet.1, h. 206-207.

Jurnal Ilmiah Al QALAM, Vol. 12, No. 1, Januari-Juni 2018 
Mardhiya Agustina: Pendidikan Islam di Suriah dan Relevansinya dengan Pendidikan Islam di Indonesia

Jika pendidikan Islam di Indonesia menghadapi tantangan kemajuan sains dan teknologi yang begitu pesat yang memberikan dampak positif dan tidak sedikit pula dampak negatifnya, juga tantangan dalam mengejar ketertinggalan dalam hal pendidikan dari negara lain, maka pendidikan di Suriah saat ini menghadapi tantangan yang jauh lebih besar yaitu sedang menghadapi krisis yang cukup memprihatinkan dalam pendidikan dengan terjadinya perang berkepanjangan di negara tersebut.

Lembaga pendidikan di Suriah sebagai salah satu pelaksana proses pendidikan yang seharusnya bertanggung jawab terhadap proses pendidikan tak lagi dapat menjalankan perannya secara maksimal. Padahal tidak semua tugas mendidik dapat dilaksanakan oleh orang tua dalam keluarga, terutama dalam hal ilmu pengetahuan dan berbagai macam keterampilan, dan sekolah yang bertanggung jawab atas pendidikan pseserta didik selama mereka diserahkan kepadanya. ${ }^{108}$ Sehingga para generasi muda Suriah terancam menjadi bagian dari masyarakat yang tidak produktif.

Sejak pecahnya perang global di Suriah sejak tahun 2011 hingga sekarang banyak anak-anak Suriah yang tak lagi dapat bersekolah dikarenakan fasilitas yang hancur dan keamanan yang tidak stabil. Bahkan banyak dari warga negara Suriah yang akhirnya mengungsi dan tinggal di camp-camp pengungsian. Diantara negara yang banyak menampung pengungsi Suriah adalah Turki. Maka selama di pengungsian, selanjutnya Turkilah yang mengambil alih pendidikan bagi anak-anak Suriah. Pada tahun akademik 20162017 pendidikan nasional Tukri mengintegrasikan hampir setengah juta anak pengungsi Suriah ke dalam sistem pendidikan mereka. ${ }^{109}$ Hal ini tentunya akan memunculkan problematika baru dimana negara yang menampung para pengungsi Suriah sedikit banyak akan memberikan dampak terhadap corak

108 Binti Maunah, Landasan Pendidikan, (Yogyakarta: Teras, 2009), cet.1, h.179.

109 Menteri Pendidikan: Turki Mendidik 500.000 Anak-Anak Suriah, https://jurnalislam.com/ menteri- pendidikan-turki-mendidik-500-000-anak-anaksuriah/, diakses pada 16 April 2018.

Jurnal Ilmiah Al QALAM, Vol. 12, No. 1, Januari-Juni 2018 
Mardhiya Agustina: Pendidikan Islam di Suriah dan Relevansinya dengan Pendidikan Islam di Indonesia

pendidikan mereka dan kemungkinan tidak sejalan dengan sistem pendidikan yang selama ini mereka terapkan.

Terlepas dari rintangan dan tantangan yang hadapi oleh Suriah maupun Indonesia dalam melaksanakan pendidikan Islam bagi warga negaranya, namun yang tidak bisa dinafikan bahwa melalui pendidikanlah sebuah negara akan maju dan berkembang. Pendidikan sangatlah berkorelasi dengan masalah peningkatan sumber daya manusia, artinya keutuhan manusia pada hakikatnya ditentukan oleh dimensi religius, budaya dan ilmiah yang ditempuh melalui proses pendidikan. ${ }^{110}$

\section{E. Penutup}

Suriah atau Syria adalah salah satu negara Arab yang berada di Timur Tengah. Pemerintahannya berbentuk republik dengan sistem presidensial. Suriah diperkirakan sebagai pusat peradaban tertua di dunia dimana putera Nabi Nuh Sham memilih untuk tinggal disana setelah bahtera Nuh merapat.

Sistem pendidikan Islam di Suriah memiliki kemiripan dengan sitem pendidikan di Indonesia. Memiliki lembaga pendidikan formal seperti madrasah, perguruan tinggi dan ma'had 'aliy. Sedangkan non formal seperti masjid, halaqah ta'lim, halaqah tahfizh al-Qur'an. Untuk jenjang pendidikannya dimulai dari tingkat dasar, persiapan, menengah dan perguruan tinggi.

Seluruh jenjang pendidikan di Suriah pada lembaga milik pemerintah adalah gratis, dan diberlakukan wajib belajar 9 tahun. Pada lembaga pendidikan formal pendidikan agama Islam mulai diajarkan pada tahun ke-3 jenjang al-madrasah al-ibtidaiyyah. Sedangkan pada lembaga non formal pendidikan Agama Islam dimulai sejak usia dini, seperti halaqah tahfizh AlQur'an.

110 Bashori Muchsin, Abdul Wahid, Pendidikan Islam Kontemporer, (Bandung: Refika Aditama, 2009), cet.1, h.66.

Jurnal Ilmiah Al QALAM, Vol. 12, No. 1, Januari-Juni 2018 
Mardhiya Agustina: Pendidikan Islam di Suriah dan Relevansinya dengan Pendidikan Islam di Indonesia

\section{Daftar Pustaka}

Al-Islam Fi Suriya, https://ar.m.wikipedia.org/wiki/الإسلام في سوريال, diakses pada 16 April 2018.

Al-Ta'lim Fi Suriya, https://ar.m.wikipedia.org/wiki/التعليم في سوريا/, diakses pada 16 April 2018.

Azra, Azyumardi. 1999. Pendidikan Islam: Tradisi dan Modernisasi Menuju Milenium Baru. Ciputat: Logos Wacana Ilmu.

Daulay, Haidar Putra. 2009. Dinamika Pendidikan Islam di Asia Tenggara. Jakarta: Rineka Cipta. cet.1

Google Play Store, Al-Maktabah Al-Madrasiyyah Al-Suriyyah.

Maunah, Binti. 2009. Landasan Pendidikan. Yogyakarta: Teras. cet.1

Menteri Pendidikan: Turki Mendidik 500.000 Anak-Anak Suriah, https://jurnalislam.com/ menteri- pendidikan-turki-mendidik-500-000anak-anak-suriah/, diakses pada 16 April 2018.

Muchsin, Bashori. Abdul Wahid. 2009. Pendidikan Islam Kontemporer, Bandung: Refika Aditama. cet.1.

Muhammad, Mahadhir. Kebijakan Politik Pemerintahan Bashar Al-Assad di Suriah, In Right Jurnal Agama dan Hak Azazi Manusia Vol.6 No.1 November 2016.

Nata, Abudin. 2004. Sejarah Pendidikan Islam: Pada Periode Klasik dan Pertengahan. Jakarta: Raja Grafindo Persada. cet.1.

Suwito. Fauzan. 2005. Sejarah Sosial Pendidikan Islam. Jakarta: Prenada Media. cet.1.

Jurnal Ilmiah Al QALAM, Vol. 12, No. 1, Januari-Juni 2018 